\title{
Yttrium $\beta$-Diketonate Glyme MOCVD Precursors: Effects of the Polyether Length on Stabilities, Mass Transport Properties and Coordination Spheres
}

\author{
Graziella Malandrino, ${ }^{[a]}$ Raffaella Lo Nigro, ${ }^{[b]}$ Ignazio L. Fragalà, ${ }^{*[a]}$ and \\ Cristiano Benelli ${ }^{[\mathrm{c}]}$
}

Keywords: Yttrium / Thermogravimetry / Superconductors

The glyme adducts of trishexafluoroacetylacetonato yttrium, [Y(hfa) $)_{3} \cdot$ monoglyme], [Y(hfa $)_{3} \cdot$ diglyme], [Y(hfa $)_{3} \cdot\left(\mathrm{H}_{2} \mathrm{O}\right)_{2} \cdot$ triglyme] and [Y(hfa $)_{2}$ 'tetraglyme $]^{+}\left[\mathrm{Y}(\mathrm{hfa})_{4}\right]^{-}\left\{\mathrm{CH}_{3}\left(\mathrm{OCH}_{2} \mathrm{CH}_{2}\right)_{n^{-}}\right.$ $\mathrm{OCH}_{3}, n=1$ monoglyme, 2 diglyme, 3 triglyme and 4 tetraglyme\}, were synthesized and characterized by elemental analysis, mass spectrometry, and IR, ${ }^{1} \mathrm{H}$ and ${ }^{13} \mathrm{C}$ NMR spectroscopy. Additionally, [Y(hfa $)_{3} \cdot$ monoglyme] and $\left[\mathrm{Y}(\mathrm{hfa})_{3} \cdot\right.$ diglyme] were characterized by single-crystal X-ray diffraction studies. The mass-transport properties of these adducts were investigated by thermogravimetric analysis, differential scanning calorimetry, evaporation-rate measure- ments and chemical vapour-deposition experiments. There is evidence of high volatility and very good thermal stabilities with a residue lower than 2-4\%. Vaporization-rate experiments proved that all adducts are well-suited for metal-organic chemical vapour-deposition experiments. The $\left[\mathrm{Y}(\mathrm{hfa})_{3} \cdot\right.$ monoglyme] complex was successfully applied in the low-pressure MOCVD process of YBaCuO HTc superconductor using a multimetal molten single source.

(ㄷ) Wiley-VCH Verlag GmbH \& Co. KGaA, 69451 Weinheim, Germany, 2004)

\section{Introduction}

New lanthanide $\beta$-diketonate adducts with polyethers ${ }^{[1-13]}$ have recently attracted particular attention because they have better properties than their parent $\beta$-diketonate precursors for MOCVD, in terms of thermal stability and volatility.

Although yttrium is not a $4 \mathrm{f}$ element, its chemistry resembles that of lanthanides and, in particular, similarities are observed either with neodymium and samarium or with holmium and erbium ions, depending on whether the nature of the bonds is predominantly covalent or ionic. ${ }^{[14]}$ Yttrium ions are present in a wide variety of materials, ranging from yttria $\left(\mathrm{Y}_{2} \mathrm{O}_{3}\right)$ and yttria-stabilized zirconia (YSZ), to optoelectronic materials such as yttrium aluminium or indium garnet (YGA and YIG respectively), or from yttrium aluminate $\left(\mathrm{YAlO}_{3}\right)$ to the superconducting metal oxide $\mathrm{YBa}_{2} \mathrm{Cu}_{3} \mathrm{O}_{7-\delta}(\mathrm{YBCO})$. The synthesis of these materials in the form of thin films, using a friendly and lowcost technique, represents a great challenge. In this context, the Metal-Organic Chemical Vapour Deposition (MOCVD) technique offers a softer approach for all these

[a] Dipartimento di Scienze Chimiche and Unità INSTM of Catania, Università di Catania

Viale Andrea Doria 6, 95125 Catania, Italy

E-mail: lfragala@dipchi.unict.it

[b] IMM-CNR, sezione di Catania,

Stradale Primosole n 50, 95121 Catania, Italy

[c] Dipartimento di Chimica and Unità INSTM of Firenze, Università di Firenze, Italy applications, with lower processing temperatures and greater throwing power (versatility and adaptability) than other alternative methodologies. ${ }^{[15]}$

To date, the conventional yttrium precursors, such as $\mathrm{Y}(\mathrm{tmhd})_{3}(\mathrm{Htmhd}=2,2,6,6$-tetramethyl-3,5-heptandione), have had several drawbacks, most notably the high quantity of residue left in commercial evaporators/bubblers and their poor stability in the atmosphere. ${ }^{[16,17]}$

In this scenario, novel monomeric, thermally stable, volatile and water-free yttrium complexes are of strategic relevance due to the lack of MOCVD precursors with suitable mass-transport properties. This consideration prompted investigations on new, suitable, highly chelated molecular architectures that inhibit oligomerization and water-coordination processes and improve the thermal stability, volatility and mass-transport properties.

It has been already demonstrated that the combined use of fluorinated $\beta$-diketonates and of ancillary-coordinated polyethers provides monomeric, volatile and thermally stable precursors of a large variety of metal ions including rare-earth metals. ${ }^{[1-7,12,13,18]}$ The same strategy was adopted for the yttrium ion, and the tailoring of the molecular architecture of the ligand framework yielded novel, very promising second-generation yttrium precursors. ${ }^{[19,20]}$ However, there is no information on the thermal and masstransport properties of all these adducts.

In this paper we report the synthesis and transport properties of the four yttrium adducts $\left[\mathrm{Y}(\mathrm{hfa})_{3} \cdot \mathrm{L}\right][$ where 
$\mathrm{Hhfa}=1,1,1,5,5,5$-hexafluoroacetylacetone, $\mathrm{L}=\mathrm{CH}_{3} \mathrm{O}$ $\left(\mathrm{CH}_{2} \mathrm{CH}_{2} \mathrm{O}\right)_{n} \mathrm{CH}_{3}$ with $n=1$ monoglyme (1,2-dimethoxyethane), 2 diglyme [bis(2-methoxyethyl)ether), [Y(hfa) ${ }_{3}$. $\left(\mathrm{H}_{2} \mathrm{O}\right)_{2}$-triglyme] [triglyme $=(2,5,8,11$-tetraoxadodecane $)$ ], and $\left[\mathrm{Y}(\mathrm{hfa})_{2} \cdot \text { tetraglyme }\right]^{+}\left[\mathrm{Y}(\mathrm{hfa})_{4}\right]^{-}, \quad$ [tetraglyme = (2,5,8,11,14-pentaoxatetradecane)]. The $\mathrm{X}$-ray single crystal structure of [Y(hfa $)_{3}$-monoglyme] is reported and the current X-ray data of $\left[\mathrm{Y}(\mathrm{hfa})_{3}\right.$. diglyme] are compared with those previously reported. Thermal stabilities and volatilities of all the adducts were evaluated and compared with those of the first-generation yttrium precursors. The use of $\left[\mathrm{Y}(\mathrm{hfa})_{3} \cdot\right.$ monoglyme in the deposition of YBCO thin films was also addressed in detail, and, finally, the effects of the polyether length on the coordination/structure, thermal stability, volatility and coordination sphere of the $\mathrm{Y}(\mathrm{hfa})_{3}$ moiety are discussed.

The aim of the present study is, therefore, the functional validation of these "second-generation" yttrium precursors, in the perspective of MOCVD applications, also in terms of a multimetal molten single source.

\section{Results}

\section{Synthesis}

The adducts of $\mathrm{Y}(\mathrm{hfa})_{3}$ with four different glymes were prepared through one-pot reactions from yttrium hydroxide, hexafluoroacetylacetone and polyether in hexane [see Equation (1)]:

$$
\begin{aligned}
& \mathrm{Y}(\mathrm{OH})_{3} \cdot n \mathrm{H}_{2} \mathrm{O}+3 \mathrm{Hhfa}+\mathrm{L} \rightarrow\left[\mathrm{Y}(\mathrm{hfa})_{3} \cdot \mathrm{L}\right]+(n+3) \mathrm{H}_{2} \mathrm{O} \\
& \text { or }\left[\mathrm{Y}(\mathrm{hfa})_{3} \cdot\left(\mathrm{H}_{2} \mathrm{O}\right)_{2} \cdot \mathrm{L}^{\prime}\right] \\
& \text { or }\left[\mathrm{Y}(\mathrm{hfa})_{2} \cdot \mathrm{L}^{\prime \prime}\right]^{+}\left[\mathrm{Y}(\mathrm{hfa})_{4}\right]^{-} \\
&\left(\mathrm{L}=\text { monoglyme, diglyme; } \mathrm{L}^{\prime}=\text { triglyme; } \mathrm{L}^{\prime \prime}=\text { tetraglyme }\right)
\end{aligned}
$$

A slight excess of yttrium hydroxide favours the isolation of the product, since the insoluble excess of $\mathrm{Y}(\mathrm{OH})_{3} \cdot n \mathrm{H}_{2} \mathrm{O}$ can be easily filtered off. The present syntheses can be efficiently carried out in hexane with good yields thus avoiding the use of carcinogenic benzene or toluene, as in the alternative syntheses already reported. ${ }^{[19,20]}$

The adducts synthesised are very soluble in common organic solvents such as ethanol, chloroform, acetone, pentane, and toluene, and slightly soluble in cyclohexane. Adducts 1-3 have low melting points and evaporate quantitatively at low temperature under vacuum. They are nonhygroscopic and can be handled in air.

\section{X-ray Single Crystal Structures of $\left[\mathrm{Y}(\mathrm{hfa})_{3} \cdot\right.$ monoglyme] and} [Y(hfa) $)_{3} \cdot$ diglyme]

The ORTEP drawing of the asymmetric unit [Y(hfa $)_{3} \cdot$ monoglyme] is shown in Figure 1. Selected bond lengths and angles are reported in Table 1. The crystal structure consists of monomeric units of molecules where an yttrium ion is in an eight coordination sphere formed by the six oxygen atoms of three hfa ligands and by two oxygen atoms of the monoglyme ligand. The coordination poly-

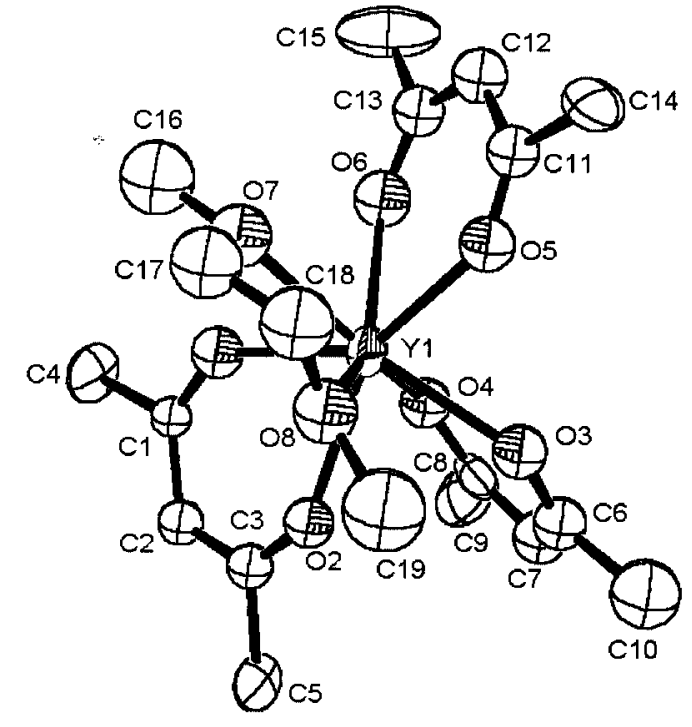

Figure 1. ORTEP drawing of the asymmetric unit of complex [Y(hfa $)_{3} \cdot$ monoglyme]; $\mathrm{CF}_{3}$ groups have been omitted for clarity; probability of thermal ellipsoids is $50 \%$

hedron around the yttrium atom is highly distorted and far from any idealized polyhedron. The average $\mathrm{Y}-\mathrm{O}(\mathrm{hfa})$ distance is $2.34 \AA$, similar to the bond lengths observed in other $\mathrm{Y}(\mathrm{hfa})_{3}$ derivatives.

The ORTEP drawing of the asymmetric unit $\left[\mathrm{Y}(\mathrm{hfa})_{3} \cdot\right.$ diglyme] is shown in Figure 2. Selected bond lengths and angles are reported in Table 2. The crystal structure consists of monomeric units of molecules where an yttrium ion is in a nine coordination sphere formed by the six oxygen atoms of three hfa ligands and by three oxygen atoms of the diglyme ligand. The $\left[\mathrm{Y}(\mathrm{hfa})_{3} \cdot\right.$ diglyme] complex possesses an orthorhombic structure. It should be noted that the structure of $\left[\mathrm{Y}(\mathrm{hfa})_{3} \cdot\right.$ diglyme $]$ has been previously published by Pollard et $\mathrm{al}^{\left[{ }^{[19]}\right.}$ but in a monoclinic habit. The average $\mathrm{Y}-\mathrm{O}(\mathrm{hfa})$ distance, observed in the current, more symmetrical structure, is $2.361 \AA, 0.015 \AA$ longer than the bond lengths observed in the monoclinic derivative $(2.346 \AA)$. Analogously, the average lenght of the $\mathrm{Y}-\mathrm{O}$ (diglyme) bonds presently observed $(2.510 \AA)$ is 0.015 $\AA$ greater than that previously reported $(2.495 \AA)$.

It is interesting to compare the structures of these adducts with those of the analogous $\mathrm{La}^{[1,4]} \mathrm{Gd},{ }^{[2]}$ and $\mathrm{Ho}^{[20]}$ derivatives. The average $\mathrm{Y}-\mathrm{O}$ lenghts observed are similar to those reported for the Gd and Ho adducts. Moreover a large difference $(0.150 \AA)$ is observed between the average $\mathrm{Y}-\mathrm{O}$ (diglyme) and the average $\mathrm{Y}-\mathrm{O}(\mathrm{hfa})$ lenghts in the [Y(hfa $)_{3} \cdot$ diglyme], which is exactly the same as that observed for the Gd derivative and much larger than that reported $(0.014 \AA)$ for the La analogue. These data may be interpreted by considering the ionic radius values of the $\mathrm{La}^{3+}(1.13 \AA), \mathrm{Gd}^{3+}(1.02 \AA), \mathrm{Y}^{3+}(0.93 \AA)$, and $\mathrm{Ho}^{3+}$ $(0.97 \AA)$ ions.

\section{NMR Spectra}

${ }^{1} \mathrm{H}$ and ${ }^{13} \mathrm{C}$ NMR spectra (see Table 3 ) were recorded in $\mathrm{CDCl}_{3}$ for adducts $\mathbf{1 - 3}$. In the case of adduct 4 , the lower 
Table 1. Selected bond lengths $[\mathrm{A}]$ and angles $\left[^{\circ}\right]$ for $\left[\mathrm{Y}(\mathrm{hfa})_{3} \cdot\right.$ monoglyme]

\begin{tabular}{|c|c|}
\hline & Bonds \\
\hline $\mathrm{Y}(1)-\mathrm{O}(6)$ & $2.322(12)$ \\
\hline $\mathrm{Y}(1)-\mathrm{O}(2)$ & $2.325(11)$ \\
\hline $\mathrm{Y}(1)-\mathrm{O}(1)$ & $2.344(10)$ \\
\hline $\mathrm{Y}(1)-\mathrm{O}(3)$ & $2.346(10)$ \\
\hline $\mathrm{Y}(1)-\mathrm{O}(4)$ & $2.353(10)$ \\
\hline $\mathrm{Y}(1)-\mathrm{O}(5)$ & $2.365(12)$ \\
\hline $\mathrm{Y}(1)-\mathrm{O}(7)$ & $2.456(12)$ \\
\hline \multirow[t]{2}{*}{$\mathrm{Y}(1)-\mathrm{O}(8)$} & $2.476(11)$ \\
\hline & Angles \\
\hline $\mathrm{O}(6)-\mathrm{Y}(1)-\mathrm{O}(2)$ & $145.9(4)$ \\
\hline $\mathrm{O}(6)-\mathrm{Y}(1)-\mathrm{O}(1)$ & 79.7(4) \\
\hline $\mathrm{O}(2)-\mathrm{Y}(1)-\mathrm{O}(1)$ & 72.3(4) \\
\hline $\mathrm{O}(6)-\mathrm{Y}(1)-\mathrm{O}(3)$ & 119.1(4) \\
\hline $\mathrm{O}(2)-\mathrm{Y}(1)-\mathrm{O}(3)$ & $76.4(4)$ \\
\hline $\mathrm{O}(1)-\mathrm{Y}(1)-\mathrm{O}(3)$ & $142.3(4)$ \\
\hline $\mathrm{O}(6)-\mathrm{Y}(1)-\mathrm{O}(4)$ & $77.9(4)$ \\
\hline $\mathrm{O}(2)-\mathrm{Y}(1)-\mathrm{O}(4)$ & $77.9(4)$ \\
\hline $\mathrm{O}(1)-\mathrm{Y}(1)-\mathrm{O}(4)$ & $78.9(3)$ \\
\hline $\mathrm{O}(3)-\mathrm{Y}(1)-\mathrm{O}(4)$ & $74.3(3)$ \\
\hline $\mathrm{O}(6)-\mathrm{Y}(1)-\mathrm{O}(5)$ & $73.9(4)$ \\
\hline $\mathrm{O}(2)-\mathrm{Y}(1)-\mathrm{O}(5)$ & $139.1(3)$ \\
\hline $\mathrm{O}(1)-\mathrm{Y}(1)-\mathrm{O}(5)$ & $145.4(4)$ \\
\hline $\mathrm{O}(3)-\mathrm{Y}(1)-\mathrm{O}(5)$ & $71.7(4)$ \\
\hline $\mathrm{O}(4)-\mathrm{Y}(1)-\mathrm{O}(5)$ & $116.0(4)$ \\
\hline $\mathrm{O}(6)-\mathrm{Y}(1)-\mathrm{O}(7)$ & $78.2(4)$ \\
\hline $\mathrm{O}(2)-\mathrm{Y}(1)-\mathrm{O}(7)$ & $111.3(4)$ \\
\hline $\mathrm{O}(1)-\mathrm{Y}(1)-\mathrm{O}(7)$ & $74.2(4)$ \\
\hline $\mathrm{O}(3)-\mathrm{Y}(1)-\mathrm{O}(7)$ & $138.3(4)$ \\
\hline $\mathrm{O}(4)-\mathrm{Y}(1)-\mathrm{O}(7)$ & $146.7(3)$ \\
\hline $\mathrm{O}(5)-\mathrm{Y}(1)-\mathrm{O}(7)$ & $78.7(4)$ \\
\hline $\mathrm{O}(6)-\mathrm{Y}(1)-\mathrm{O}(8)$ & $136.4(5)$ \\
\hline $\mathrm{O}(2)-\mathrm{Y}(1)-\mathrm{O}(8)$ & $72.7(4)$ \\
\hline $\mathrm{O}(1)-\mathrm{Y}(1)-\mathrm{O}(8)$ & $108.9(4)$ \\
\hline $\mathrm{O}(3)-\mathrm{Y}(1)-\mathrm{O}(8)$ & $80.6(4)$ \\
\hline $\mathrm{O}(4)-\mathrm{Y}(1)-\mathrm{O}(8)$ & $145.1(4)$ \\
\hline $\mathrm{O}(5)-\mathrm{Y}(1)-\mathrm{O}(8)$ & $77.3(4)$ \\
\hline $\mathrm{O}(7)-\mathrm{Y}(1)-\mathrm{O}(8)$ & $64.4(4)$ \\
\hline
\end{tabular}

solubility in $\mathrm{CDCl}_{3}$ required $\left(\mathrm{CD}_{3}\right)_{2} \mathrm{CO}$ and $\mathrm{C}_{6} \mathrm{D}_{6}$ for ${ }^{1} \mathrm{H}$ and ${ }^{13} \mathrm{C}$ NMR spectroscopy, respectively. The ${ }^{1} \mathrm{H}$ NMR spectra always show a singlet around $6.0 \mathrm{ppm}$ associated with the alkene proton of the hfa ligand. Different resonances are associated with the polyether framework and the related values are reported in Table 3. The spectrum of 3 contains a resonance $(\delta=3.94 \mathrm{ppm})$ associated with the coordinated $\mathrm{H}_{2} \mathrm{O}$. The intensities of pertinent resonances point to a 3:2:1 (hfa: $\mathrm{H}_{2} \mathrm{O}:$ triglyme) ratio.

The evaluation of the relative intensities of hfa and tetraglyme resonances of adduct 4 points to a 6:1 (hfa:tetraglyme) ratio. This observation may be accounted for by considering an ionic structure $\left[\mathrm{Y}(\mathrm{hfa})_{2} \cdot\right.$ tetraglyme $^{+}$$\left[\mathrm{Y}(\mathrm{hfa})_{4}\right]^{-}$, as previously proposed by Pollard et al. ${ }^{[19]}$

The ${ }^{13} \mathrm{C} \mathrm{NMR}\left(\mathrm{CDCl}_{3}\right)$ spectra can be assigned by comparison with the data of related lanthanum complexes. ${ }^{[1,3,4]}$ Details of associated resonances are reported in Table 3.

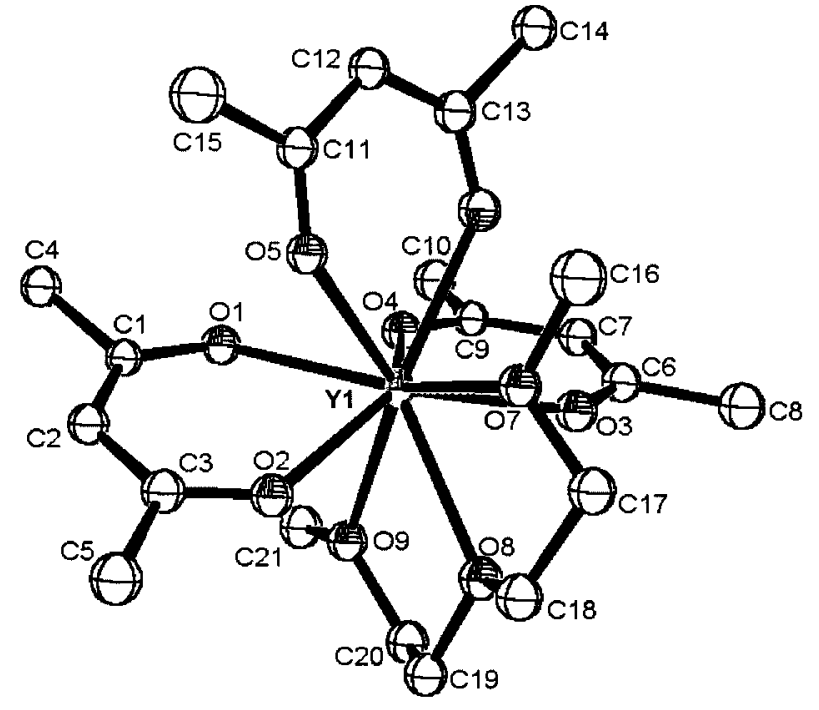

Figure 2. ORTEP drawing of the crystal structure of $\left[\mathrm{Y}(\mathrm{hfa})_{3} \cdot\right.$ diglyme]; $\mathrm{CF}_{3}$ groups have been omitted for clarity; probability of thermal ellipsoids is $50 \%$

\section{Mass Spectra}

The $\mathrm{FAB}^{+}$spectra of the adducts $\mathbf{1 - 4}$ are reported in Table 4 . The spectra show fragment peaks due to fragmentation of both the hfa and polyether ligands. In addition, there is evidence of the characteristic fluorine-transfer process, already observed in the spectra of the analogous alkaline-earth ${ }^{[18,21]}$ and lanthanide ( $\left.\mathrm{La}, \mathrm{Gd}, \mathrm{Eu}\right)$ adducts. $^{[2,4,6]}$ The fluorine-transfer process preludes a fluoride phase formation that could contaminate the deposited films, unless appropriate conditions are used. No molecular ion peaks or peaks at higher mass were observed for the adducts. The major peak of all the adducts corresponds to the ion $\left[\mathrm{Y}(\mathrm{hfa})_{2} \cdot \mathrm{L}\right]^{+}$. At lower mass values, the more abundant peaks correspond to the fragments $[\mathrm{Y}(\mathrm{hfa}) \cdot \mathrm{L}+\mathrm{F}]^{+},[\mathrm{Y} \cdot \mathrm{L}$ $+2 \mathrm{~F}]^{+},\left[\mathrm{Y}(\mathrm{hfa})_{2}\right]^{+},[\mathrm{Y}(\mathrm{hfa})+\mathrm{F}]^{+}$.

\section{Infrared Spectra}

The IR spectra of the raw and sublimed adducts are identical. The absence of any bands around 3300-3600 $\mathrm{cm}^{-1}$ in the spectrum of $\mathbf{1}, \mathbf{2}$ and $\mathbf{4}$ is indicative of $\mathrm{H}_{2} \mathrm{O}$ free species. In contrast, the broad bands at $3380 \mathrm{~cm}^{-1}$ and $3260 \mathrm{~cm}^{-1}$ in the spectrum of $\mathbf{3}$ are associated with coordinated water (see below). In addition all the spectra show the characteristic peaks at $1660 \mathrm{~cm}^{-1}$ and $1500-1550 \mathrm{~cm}^{-1}$ associated with $\mathrm{C}=\mathrm{O}$ and $\mathrm{C}=\mathrm{C}$ stretching, respectively. The characteristic trend of peaks at 1255, 1210, 1140 and 1100 $\mathrm{cm}^{-1}$ arises from the overlap of the band due to $\mathrm{C}-\mathrm{F}$ stretching and those associated with $\mathrm{C}-\mathrm{O}$ stretching. The peaks between 800 and $1050 \mathrm{~cm}^{-1}$ may be considered fingerprints of the glyme coordination to the yttrium hexafluoroacetylacetonate moiety.

\section{Mass-Transport Properties}

The thermal characteristics of the raw adducts were studied by atmospheric-pressure thermogravimetric (TG) analy- 
Table 2. Selected bond lengths $[\mathrm{A}]$ and angles $\left[^{\circ}\right]$ for $\left[\mathrm{Y}(\mathrm{hfa})_{3} \cdot\right.$ diglyme $]$

\begin{tabular}{|c|c|}
\hline & Bonds \\
\hline $\mathrm{Y}(1)-\mathrm{O}(1)$ & $2.334(7)$ \\
\hline $\mathrm{Y}(1)-\mathrm{O}(3)$ & $2.335(6)$ \\
\hline $\mathrm{Y}(1)-\mathrm{O}(2)$ & $2.347(8)$ \\
\hline $\mathrm{Y}(1)-\mathrm{O}(6)$ & $2.352(8)$ \\
\hline $\mathrm{Y}(1)-\mathrm{O}(4)$ & $2.384(7)$ \\
\hline $\mathrm{Y}(1)-\mathrm{O}(5)$ & $2.415(8)$ \\
\hline $\mathrm{Y}(1)-\mathrm{O}(7)$ & $2.477(6)$ \\
\hline $\mathrm{Y}(1)-\mathrm{O}(9)$ & $2.487(7)$ \\
\hline \multirow[t]{2}{*}{$\mathrm{Y}(1)-\mathrm{O}(8)$} & $2.522(7)$ \\
\hline & Angles \\
\hline $\mathrm{O}(1)-\mathrm{Y}(1)-\mathrm{O}(3)$ & $142.7(2)$ \\
\hline $\mathrm{O}(1)-\mathrm{Y}(1)-\mathrm{O}(2)$ & $73.6(2)$ \\
\hline $\mathrm{O}(3)-\mathrm{Y}(1)-\mathrm{O}(2)$ & $135.1(3)$ \\
\hline $\mathrm{O}(1)-\mathrm{Y}(1)-\mathrm{O}(6)$ & $99.7(2)$ \\
\hline $\mathrm{O}(3)-\mathrm{Y}(1)-\mathrm{O}(6)$ & $72.6(3)$ \\
\hline $\mathrm{O}(2)-\mathrm{Y}(1)-\mathrm{O}(6)$ & $140.6(3)$ \\
\hline $\mathrm{O}(1)-\mathrm{Y}(1)-\mathrm{O}(4)$ & $70.5(2)$ \\
\hline $\mathrm{O}(3)-\mathrm{Y}(1)-\mathrm{O}(4)$ & $72.6(2)$ \\
\hline $\mathrm{O}(2)-\mathrm{Y}(1)-\mathrm{O}(4)$ & $136.6(2)$ \\
\hline $\mathrm{O}(6)-\mathrm{Y}(1)-\mathrm{O}(4)$ & $70.1(2)$ \\
\hline $\mathrm{O}(1)-\mathrm{Y}(1)-\mathrm{O}(5)$ & $69.6(2)$ \\
\hline $\mathrm{O}(3)-\mathrm{Y}(1)-\mathrm{O}(5)$ & $134.0(2)$ \\
\hline $\mathrm{O}(2)-\mathrm{Y}(1)-\mathrm{O}(5)$ & $72.0(3)$ \\
\hline $\mathrm{O}(6)-\mathrm{Y}(1)-\mathrm{O}(5)$ & $69.3(3)$ \\
\hline $\mathrm{O}(4)-\mathrm{Y}(1)-\mathrm{O}(5)$ & $115.6(2)$ \\
\hline $\mathrm{O}(1)-\mathrm{Y}(1)-\mathrm{O}(7)$ & $139.3(2)$ \\
\hline $\mathrm{O}(3)-\mathrm{Y}(1)-\mathrm{O}(7)$ & $76.3(2)$ \\
\hline $\mathrm{O}(2)-\mathrm{Y}(1)-\mathrm{O}(7)$ & $82.0(2)$ \\
\hline $\mathrm{O}(6)-\mathrm{Y}(1)-\mathrm{O}(7)$ & $79.2(2)$ \\
\hline $\mathrm{O}(4)-\mathrm{Y}(1)-\mathrm{O}(7)$ & $141.4(2)$ \\
\hline $\mathrm{O}(5)-\mathrm{Y}(1)-\mathrm{O}(7)$ & $72.1(2)$ \\
\hline $\mathrm{O}(1)-\mathrm{Y}(1)-\mathrm{O}(9)$ & $76.1(2)$ \\
\hline $\mathrm{O}(3)-\mathrm{Y}(1)-\mathrm{O}(9)$ & $87.2(2)$ \\
\hline $\mathrm{O}(2)-\mathrm{Y}(1)-\mathrm{O}(9)$ & $76.9(2)$ \\
\hline $\mathrm{O}(6)-\mathrm{Y}(1)-\mathrm{O}(9)$ & $140.4(2)$ \\
\hline $\mathrm{O}(4)-\mathrm{Y}(1)-\mathrm{O}(9)$ & $71.6(2)$ \\
\hline $\mathrm{O}(5)-\mathrm{Y}(1)-\mathrm{O}(9)$ & $138.8(2)$ \\
\hline $\mathrm{O}(7)-\mathrm{Y}(1)-\mathrm{O}(9)$ & $129.4(2)$ \\
\hline $\mathrm{O}(1)-\mathrm{Y}(1)-\mathrm{O}(8)$ & $129.1(2)$ \\
\hline $\mathrm{O}(3)-\mathrm{Y}(1)-\mathrm{O}(8)$ & $67.5(2)$ \\
\hline $\mathrm{O}(2)-\mathrm{Y}(1)-\mathrm{O}(8)$ & $67.7(2)$ \\
\hline $\mathrm{O}(6)-\mathrm{Y}(1)-\mathrm{O}(8)$ & $131.3(2)$ \\
\hline $\mathrm{O}(4)-\mathrm{Y}(1)-\mathrm{O}(8)$ & $120.4(2)$ \\
\hline $\mathrm{O}(5)-\mathrm{Y}(1)-\mathrm{O}(8)$ & $124.0(2)$ \\
\hline $\mathrm{O}(7)-\mathrm{Y}(1)-\mathrm{O}(8)$ & $65.3(2)$ \\
\hline $\mathrm{O}(9)-\mathrm{Y}(1)-\mathrm{O}(8)$ & $64.1(2)$ \\
\hline
\end{tabular}

sis, differential scanning calorimetry (DSC) and atmospheric pressure TG vaporization-rate experiments. ${ }^{[22]}$ The TG curves of 1-4 are reported in Figure 3. Single sublimation steps are observed for the monoglyme, diglyme and tetraglyme adducts. The monoglyme adduct shows a $96 \%$ weight loss in the $79-220{ }^{\circ} \mathrm{C}$ range with a $4 \%$ residue left at $275{ }^{\circ} \mathrm{C}$. Adducts 2 and $\mathbf{4}$ show a weight loss in the $90-260{ }^{\circ} \mathrm{C}$ (residue $=2 \%$ to $300{ }^{\circ} \mathrm{C}$ ) and $170-330{ }^{\circ} \mathrm{C}$ (residue $=4 \%$ to $400{ }^{\circ} \mathrm{C}$ ) temperature ranges, respectively. The triglyme adduct shows two distinct sublimation steps corresponding to weight losses of $29 \%$ in the temperature range $80-230{ }^{\circ} \mathrm{C}$ and $60 \%$ in the temperature range
$230-300{ }^{\circ} \mathrm{C}$. The first step is probably due to the loss of the triglyme and coordinated $\mathrm{H}_{2} \mathrm{O}$ molecules, whose corresponding weight loss is about $22 \%$.

When TG atmospheric-pressure vaporization rates of adducts 1-4 are compared to the data of $\left[\mathrm{Y}(\mathrm{tmhd})_{3} \cdot \mathrm{H}_{2} \mathrm{O}\right]$ in Figure 4, it becomes evident that adducts $\mathbf{1}$ and $\mathbf{2}$ are more volatile than the "first-generation" $\left[\mathrm{Y}(\mathrm{tmhd}){ }_{3} \cdot \mathrm{H}_{2} \mathrm{O}\right]$ precursor, and in particular, vaporize approximately four and two times faster than $\left[\mathrm{Y}(\mathrm{tmhd})_{3} \cdot \mathrm{H}_{2} \mathrm{O}\right]$, respectively. Adduct 3 shows a nonlinear behaviour of the vaporization rate confirming that partial decomposition may occur during vaporization. The low volatility of adduct $\mathbf{4}$ is probably due to its ionic structure: $\left[\mathrm{Y}(\mathrm{hfa})_{2} \text { tetraglyme }\right]^{+}\left[\mathrm{Y}(\mathrm{hfa})_{4}\right]^{-}$.

The DSC data (see Figure 5) of these adducts show some interesting features in addition to the melting and evaporation processes. The DSC curve of the monoglyme adduct shows two endothermic peaks at $75.7{ }^{\circ} \mathrm{C}$ associated with the melting of the product and at approximately $175^{\circ} \mathrm{C}$ due to evaporation. Similarly the DSC curve of adduct 2 shows two endothermic peaks associated with melting $\left(62.2^{\circ} \mathrm{C}\right)$ and evaporation processes (about $150{ }^{\circ} \mathrm{C}$ ), respectively. Moreover, there is evidence at $220^{\circ} \mathrm{C}$ of an exothermic peak that is observed in the freshly prepared as well as in the aged (over 4 months) samples.

The DSC data of adduct $\mathbf{3}$ show an unusually broad endothermic peak at $53.8^{\circ} \mathrm{C}$, which can be mainly associated with the melting of the product. Nevertheless, it is likely that another kind of process, that is, a solid-phase transition peak, may be hidden under the same peak. A second endothermic peak (at around $250{ }^{\circ} \mathrm{C}$ ) is associated with the evaporation of the adduct. Similarly to adduct $\mathbf{2}$, an exothermic peak is observed at $235^{\circ} \mathrm{C}$.

Adduct 4 shows two endothermic peaks at $176.9^{\circ} \mathrm{C}$, associated with the melting process, and at approximately 275 ${ }^{\circ} \mathrm{C}$, due to evaporation. An exothermic peak was also found at $248.6^{\circ} \mathrm{C}$.

\section{MOCVD YBCO Deposition From a Molten Multimetal Single Source}

The $\left[\mathrm{Y}(\mathrm{hfa})_{3} \cdot\right.$ monoglyme] adduct was successfully employed in a novel, strategic approach to grow $\mathrm{YBa}_{2} \mathrm{Cu}_{3} \mathrm{O}_{7-\delta}$ (YBCO) films on $\mathrm{LaAlO}_{3}$ (100) substrates by MOCVD.

The synthesis of any multielement oxide film always introduces complications in the growth process due to the different physico-chemical properties of each single precursor that, of course, requires specific optimization. Recently we reported a new, very simple, low-cost route to high quality $\mathrm{LaAlO}_{3}$ (100) films on $\mathrm{SrTiO}_{3}$ (100) substrates adopting a multimetal molten single source. ${ }^{[23]}$ The novelty of the approach relies upon the use of the $\left[\mathrm{La}(\mathrm{hfa})_{3}\right.$.diglyme] complex as a solvent for the aluminum precursor $\mathrm{Al}(\mathrm{acac})_{3}$ (Hacac $=$ acetylacetone), thus affording a two-component molten source. The same approach was adopted in the current study and the $\left[\mathrm{Y}(\mathrm{hfa})_{3} \cdot\right.$ monoglyme] complex was used as a solvent for the $\mathrm{Ba}$ and $\mathrm{Cu}$ precursors. Deposition parameters were, therefore, optimized for the single multimetal source. 
Table 3. ${ }^{1} \mathrm{H}$ and ${ }^{13} \mathrm{C}$ NMR spectroscopy data of adducts $\mathbf{1}, \mathbf{2}, \mathbf{3}$ and 4

\begin{tabular}{|c|c|c|c|c|c|c|c|}
\hline \multirow[t]{2}{*}{ Complex } & \multicolumn{3}{|c|}{${ }^{1} \mathrm{H}$ NMR } & \multirow[b]{2}{*}{$-\mathrm{CO}-\mathrm{CH}-\mathrm{CO}$} & \multirow[b]{2}{*}{$-\mathrm{CO}-\mathrm{CH}-\mathrm{CO}$} & \multicolumn{2}{|l|}{${ }^{13} \mathrm{C}$ NMR } \\
\hline & $-\mathrm{CO}-\mathrm{CH}-\mathrm{CO}$ & $\mathrm{H}_{2} \mathrm{O}$ & polyether ${ }^{[a]}$ & & & $-\mathrm{CF}_{3}$ & polyether $^{[a]}$ \\
\hline$\left[\mathrm{Y}(\mathrm{hfa})_{3} \cdot\right.$ monoglyme $]$ & $6.20(\mathrm{~s}, 3 \mathrm{H})$ & & $\begin{array}{l}\text { a } 3.63(\mathrm{~s}, 6 \mathrm{H}) \text {, } \\
\text { b } 3.83(\mathrm{~s}, 4 \mathrm{H})\end{array}$ & $91.72(\mathrm{~s})$ & $\begin{array}{l}178.06 \\
\left(\mathrm{q},{ }^{2} J=35 \mathrm{~Hz}\right)\end{array}$ & $\begin{array}{l}117.40 \\
\left(\mathrm{q},{ }^{1} J=283 \mathrm{~Hz}\right)\end{array}$ & $\begin{array}{l}\text { a } 61.36 \\
\text { b } 71.49\end{array}$ \\
\hline$\left[\mathrm{Y}(\mathrm{hfa})_{3} \cdot\right.$ diglyme $]$ & $6.10(\mathrm{~s}, 3 \mathrm{H})$ & & $\begin{array}{l}\text { a } 3.46(\mathrm{~s}, 6 \mathrm{H}) \\
\text { b, c } 3.83(\mathrm{~m}, 8 \mathrm{H})\end{array}$ & $90.71(\mathrm{~s})$ & $\begin{array}{l}176.82 \\
\left(\mathrm{q},{ }^{2} J=36 \mathrm{~Hz}\right)\end{array}$ & $\begin{array}{l}117.60 \\
\left(\mathrm{q},{ }^{1} J=283 \mathrm{~Hz}\right)\end{array}$ & $\begin{array}{l}\text { a } 60.46 \\
\text { b } 70.72, \\
\text { c } 71.11\end{array}$ \\
\hline$\left[\mathrm{Y}(\mathrm{hfa})_{3} \cdot\left(\mathrm{H}_{2} \mathrm{O}\right)_{2} \cdot\right.$ triglyme $]$ & $6.10(\mathrm{~s}, 3 \mathrm{H})$ & $3.89(\mathrm{~s}, 4 \mathrm{H})^{[\mathrm{b}]}$ & $\begin{array}{l}\text { a } 3.40(\mathrm{~s}, 6 \mathrm{H}), \\
\text { b, c } 3.68(\mathrm{~m}, 8 \mathrm{H}), \\
\text { d } 3.76(\mathrm{~s}, 4 \mathrm{H})\end{array}$ & $90.85(\mathrm{~s})$ & $\begin{array}{l}177.08 \\
\left(\mathrm{q},{ }^{2} J=35 \mathrm{~Hz}\right)\end{array}$ & $\begin{array}{l}117.54 \\
\left(\mathrm{q},{ }^{1} J=284 \mathrm{~Hz}\right)\end{array}$ & $\begin{array}{l}\text { a } 59.07 \\
\text { b } 70.24 \\
\text { c } 70.48 \\
\text { d } 71.67\end{array}$ \\
\hline$[\mathrm{Y}(\mathrm{hfa}) \text { tetraglyme }]^{+}\left[\mathrm{Y}(\mathrm{hfa})_{4}\right]^{-[\mathrm{cc}]}$ & $6.17(\mathrm{~s}, 6 \mathrm{H})$ & & $\begin{array}{l}\text { a } 3.30(\mathrm{~s}, 6 \mathrm{H}) \\
\text { b, c } 3.53(\mathrm{~m}, 8 \mathrm{H}), \\
\text { d, e } 3.59(\mathrm{~s}, 8 \mathrm{H})\end{array}$ & $89.60(\mathrm{~s})$ & $\begin{array}{l}177.20 \\
\left(\mathrm{q},{ }^{2} J=34 \mathrm{~Hz}\right)\end{array}$ & $\begin{array}{l}117.79 \\
\left(\mathrm{q},{ }^{1} J=283 \mathrm{~Hz}\right)\end{array}$ & $\begin{array}{l}\text { a } 58.46 \\
\text { b } 70.74, \\
\text { c } 70.92 \\
\text { d } 72.34\end{array}$ \\
\hline
\end{tabular}

[a] The following notation has been used from monoglyme $\left(\mathrm{CHa}_{3}-\mathrm{O}-\mathrm{CH} \mathbf{b}_{2}\right)_{2}$ through tetraglyme $\left(\mathrm{CHa}_{3}-\mathrm{O}-\mathrm{CH} \mathbf{b}_{2}-\mathrm{CH} \mathbf{c}_{2}-\mathrm{O}-\mathrm{CH} \mathbf{d}_{2} \mathrm{CHe}\right)_{2} \mathrm{O}$.

[b] The position of the water peak moves with concentration. ${ }^{[c]}$ The ${ }^{1} \mathrm{H}$ NMR spectrum was recorded in acetone, while the ${ }^{13} \mathrm{C}$ NMR spectrum was recorded in $\mathrm{C}_{6} \mathrm{D}_{6}$.

Table 4. Major peaks in the mass spectra of adducts $\mathbf{1}, \mathbf{2}, \mathbf{3}$ and $\mathbf{4}$

\begin{tabular}{lllll}
\hline Assignment & {$\left[\mathrm{Y}(\mathrm{hfa})_{3} \cdot \operatorname{monoglyme}\right]$} & {$\left[\mathrm{Y}(\mathrm{hfa})_{3} \cdot\right.$ diglyme $]$} & {$\left[\mathrm{Y}(\mathrm{hfa})_{3} \cdot\left(\mathrm{H}_{2} \mathrm{O}\right)_{2} \cdot\right.$ triglyme $]$} & {$\left[\mathrm{Y}(\mathrm{hfa})_{2} \cdot \text { tetraglyme }\right]^{+}\left[\mathrm{Y}(\mathrm{hfa})_{4}\right]^{-}$} \\
\hline$[\mathrm{M}-(\mathrm{hfa})]^{+}$ & $593(100 \%)$ & $637(100 \%)$ & $681(100 \%)$ & $725(100 \%)$ \\
{$[\mathrm{M}-2(\mathrm{hfa})+\mathrm{F}]^{+}$} & $405(50 \%)$ & $449(46 \%)$ & $494(80 \%)$ & $537(54 \%)$ \\
{$[\mathrm{M}-(\mathrm{hfa})-\mathrm{L}]^{+}$} & $503(11 \%)$ & $315(27 \%)$ & & $503(20 \%)$ \\
{$[\mathrm{M}-2(\mathrm{hfa})-\mathrm{L}+\mathrm{F}]^{+}$} & $315(10 \%)$ & $261(78 \%)$ & & $315(22 \%)$ \\
{$[\mathrm{M}-3(\mathrm{hfa})+2 \mathrm{~F}]^{+}$} & $217(85 \%)$ & $126(81 \%)$ & $126(50 \%)$ & $349(75 \%)$ \\
{$\left[\mathrm{YF}_{2}\right]^{+}$} & $126(70 \%)$ & &
\end{tabular}

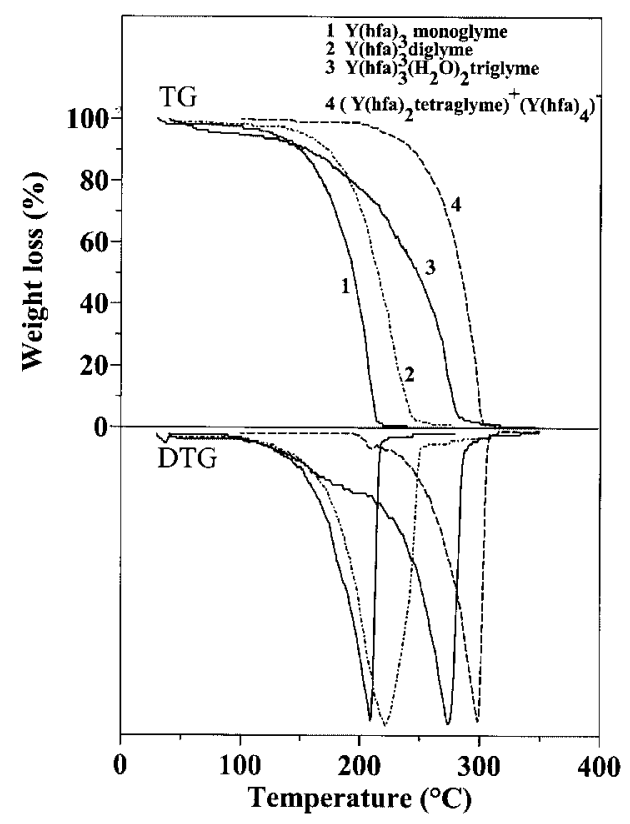

Figure 3. TG-DTG curves of adducts $\mathbf{1 - 4}$

Systematic studies were carried out by changing operational parameters governing both deposition and cooling-annealing processes. The best operative parameters for the growth of high quality YBCO films are the following: i) a single molten multimetal source consisting of

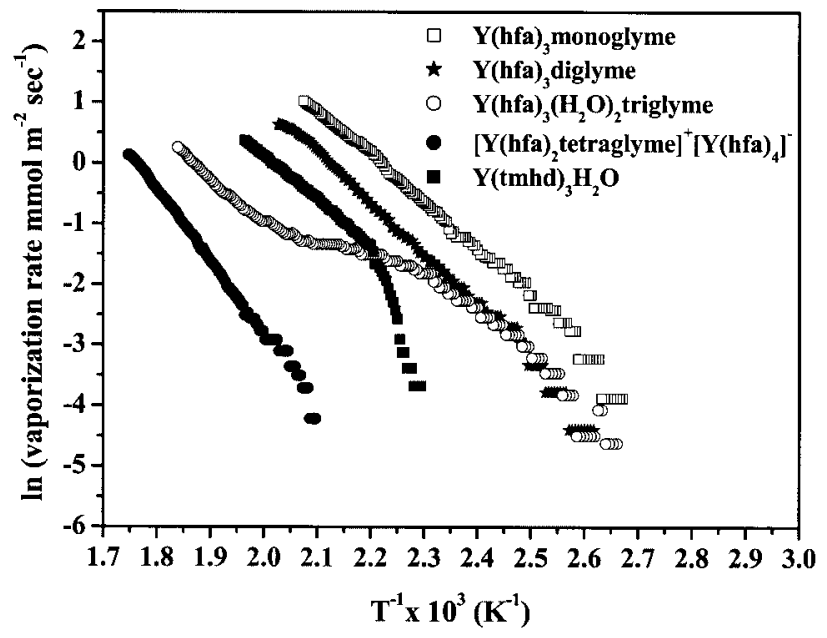

Figure 4. Atmospheric-pressure TG vaporization-rate data of adducts 1-4

a mixture of [Y(hfa $)_{3} \cdot$ monoglyme], $\left[\mathrm{Ba}(\mathrm{hfa})_{2} \cdot\right.$ tetraglyme] and $\mathrm{Cu}(\mathrm{tmhd})_{2}$ complexes (where Htmhd $=2,2,6,6$-tetramethyl-3,5-heptanedione) in the 1:2:0.5 Y:Ba:Cu ratio; ii) argon carrier gas $(300 \mathrm{sccm})$; iii) $200 \mathrm{sccm}$ flow of watersaturated oxygen as a reaction gas; iv) deposition temperature of $800^{\circ} \mathrm{C}$; v) deposition time of 3 hours, and vi) annealing at $500{ }^{\circ} \mathrm{C}$ in oxygen ambient for 12 hours.

In Figure 6 the DSC curve of the 1:2:0.5 (Y:Ba:Cu) mixture is compared with the curves of each individual precur- 


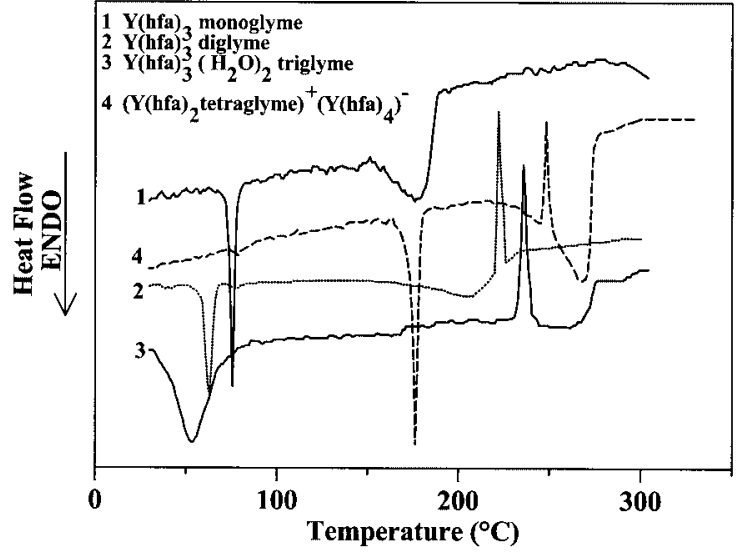

Figure 5. DSC curves of adducts $\mathbf{1 - 4}$

sor. The DSC scans of the single $\left[\mathrm{Y}(\mathrm{hfa})_{3} \cdot \operatorname{monoglyme}\right]$, $\left[\mathrm{Ba}(\mathrm{hfa})_{2} \cdot\right.$ tetraglyme $]$ and $\mathrm{Cu}(\mathrm{tmhd})_{2}$ precursors show evidence of the endothermic peaks due to melting $\left\{75.7^{\circ} \mathrm{C}\right.$ for [Y(hfa) $)_{3} \cdot$ monoglyme], $153.6{ }^{\circ} \mathrm{C}$ for $\left[\mathrm{Ba}(\mathrm{hfa})_{2} \cdot{ }^{\circ}\right.$ tetraglyme], and $196.3{ }^{\circ} \mathrm{C}$ for $\left.\mathrm{Cu}(\mathrm{tmhd})_{2}\right\}$ and to evaporation from the melts in the $150-190{ }^{\circ} \mathrm{C}, 260-290{ }^{\circ} \mathrm{C}$, and $210-260{ }^{\circ} \mathrm{C}$ temperature ranges, respectively. The DSC scan of the multicomponent precursor mixture shows a lower temperature peak $\left(73.5{ }^{\circ} \mathrm{C}\right)$ representing the melting of the $\left[\mathrm{Y}(\mathrm{hfa})_{3} \cdot\right.$ monoglyme] component. The following endothermic broad peak in the $110-160{ }^{\circ} \mathrm{C}$ temperature range clearly represents dissolution of $\left[\mathrm{Ba}(\mathrm{hfa})_{2} \cdot\right.$ tetraglyme $]$ and $\mathrm{Cu}(\mathrm{tmhd})_{2}$. Finally the endothermic process at the highest temperature $\left(190-270{ }^{\circ} \mathrm{C}\right)$ is associated with the evaporation of the melted mixture. In this context the endothermic peaks expected for $\left[\mathrm{Ba}(\mathrm{hfa})_{2} \cdot\right.$ tetraglyme $]$ and $\mathrm{Cu}(\mathrm{tmhd})_{2}$ melting, at $153.6^{\circ} \mathrm{C}$ and $196.3{ }^{\circ} \mathrm{C}$, respectively, are not observed.

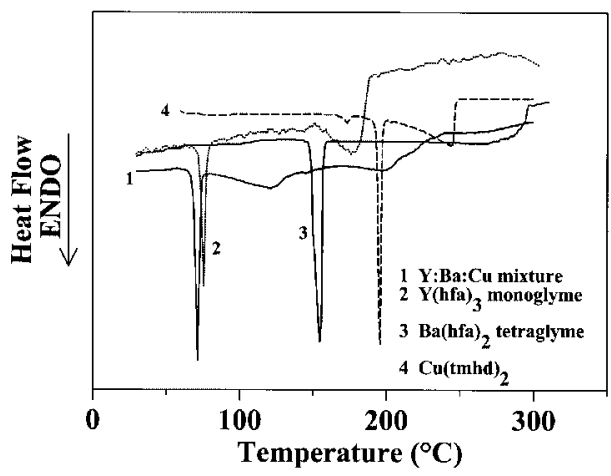

Figure 6. DSC curve of the 1:2:0.5 (Y:Ba:Cu) multimetal single source mixture compared with data of individual precursors $\left[\mathrm{Y}(\mathrm{hfa})_{3} \cdot\right.$ monoglyme], $\left[\mathrm{Ba}(\mathrm{hfa})_{2} \cdot\right.$ tetraglyme $]$, and $\mathrm{Cu}(\mathrm{tmhd})_{2}$

Great attention was devoted to the oxygen partial pressure during the cooling-annealing process, because of its influence on the phase transition from the tetrahedral to the orthorhombic phase. Thus, YBCO films were slowly cooled $\left(3^{\circ} \mathrm{C} / \mathrm{min}\right)$ under low pressure $(10$ Torr $)$ and then maintained at $500{ }^{\circ} \mathrm{C}$ under oxygen flow for 12 hours. The chemical composition of the YBCO samples, determined

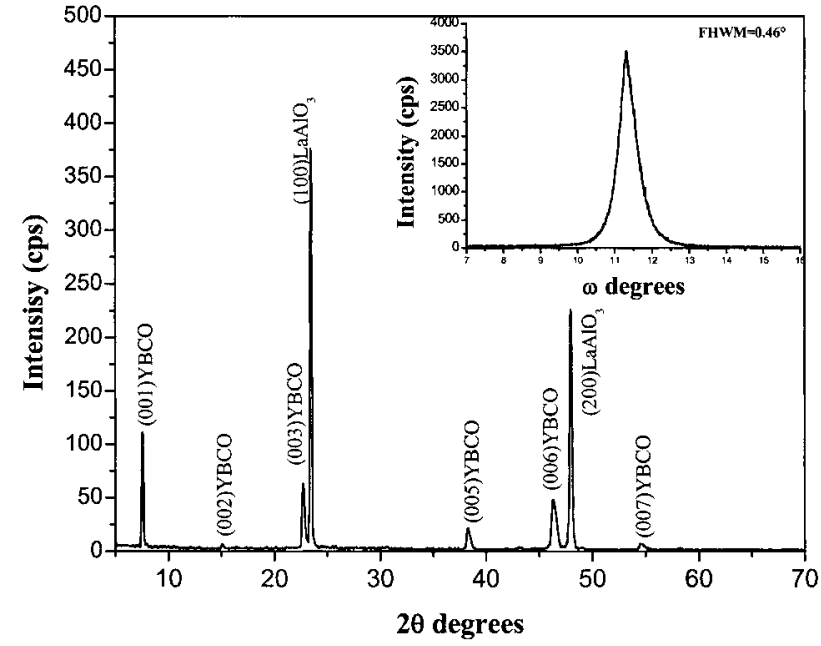

Figure 7. X-ray diffraction pattern of an MOCVD grown YBCO film on an $\mathrm{LaAlO}_{3}$ (100) substrate; the inset shows the rocking curve of the YBCO (003) reflection

with a windowless EDX detector, indicates the correct 1:2:3 $\mathrm{Y}: \mathrm{Ba}: \mathrm{Cu}$ ratio. No fluorine atoms were detected. The X-ray diffraction pattern of a typical YBCO film deposited on $\mathrm{LaAlO}_{3}(100)$ substrates is shown in Figure 7. All the reflections are indexed as $(00 l)$ peaks, thus indicating that the films are strongly $c$-axis aligned. The degree of $c$-axis alignment was determined by $\omega$-scans (rocking curve) of the (003) YBCO peak. The FWHM value of $0.46^{\circ}$ indicates a high degree of texturing. The in-plane ( $a$-and $b$-axes) alignment was established by recording the (103) pole figure. The intense four poles at $\Psi=46^{\circ}$ observed every $90^{\circ}$ of $\varphi$ in the (103) pole figure indicate a good in-plane orientation of the YBCO films on the $\mathrm{LaAlO}_{3}(100)$ substrate.

Finally, the surface morphology of the YBCO films was observed by scanning electron microscopy. All the prepared samples show smooth surfaces with "platelike" grains. Preliminary measurements of electrical transport properties give a critical temperature $\left(T_{\mathrm{c}}\right)$ value of $83 \mathrm{~K}$ and a critical current density $\left(J_{\mathrm{c}}\right)$ of $10^{5} \mathrm{~A} / \mathrm{cm}^{2}$

\section{Discussion}

The present syntheses reinforce our earlier assertion that this one-pot route is a "general" strategy for the preparation of alkaline-earth $(\mathrm{M}=\mathrm{Ba}, \mathrm{Sr} \text {, and } \mathrm{Ca})^{[18]}$ and rareearth $^{[1-6]}$ volatile and thermally stable metal adducts suitable for MOCVD applications. This synthetic procedure involves open-bench manipulations and yields, reproducibly, the water-free products $\mathbf{1}, \mathbf{2}$ and $\mathbf{4}$, despite $\mathrm{Y}(\mathrm{OH})_{3} \cdot n \mathrm{H}_{2} \mathrm{O}$ being the reagent. Therefore, polyethers act as hard Lewis bases, which encapsulate the metal ion and favourably compete with $\mathrm{H}_{2} \mathrm{O}$ in saturating the coordination sphere around the metal. Only in the case of the triglyme adduct, some $\mathrm{H}_{2} \mathrm{O}$ molecules were found to be coordinated to the yttrium centre as indicated by the presence of the band at about $3600 \mathrm{~cm}^{-1}$ in the IR spectrum. The related X-ray single 
crystal structure (see Exp. Sect.) points to an outer-sphere complex $\left[\mathrm{Y}(\mathrm{hfa})_{3} \cdot\left(\mathrm{H}_{2} \mathrm{O}\right)_{2}\right.$.triglyme]. In addition, the ${ }^{1} \mathrm{H}$ NMR integration is indicative of a 3:2:1 (hfa: $\mathrm{H}_{2} \mathrm{O}$ :triglyme) ratio and the fingerprint region of the IR spectrum points to a different and probably weaker coordination. It is interesting to observe that the outer-sphere complex is immediately formed with the current synthetic strategy, while it is originated by sublimation from the ionic structure $\left[\mathrm{Y}(\mathrm{hfa})_{2} \cdot\right.$ triglyme $^{+}\left[\mathrm{Y}(\mathrm{hfa})_{4}\right]^{-}$obtained by Pollard et al. ${ }^{[19]}$

The vaporization behaviour of adduct 3 , which depends on the coordinated $\mathrm{H}_{2} \mathrm{O}$, deserves some further comments. It was already mentioned (see above) that the triglyme adduct shows two thermogravimetric step losses, thus indicating evaporation accompanied by a partial decomposition of the precursor. This behaviour has already been observed in other hydrated compounds. Therefore, $\mathrm{H}_{2} \mathrm{O}$ is not an "innocent" or "spectator" ligand, but it plays a key role in the chemistry of this MOCVD precursor, similarly to the previous behaviour reported by Luten et al. for $\left[\mathrm{Y}(\mathrm{tmhd})_{3} \cdot \mathrm{H}_{2} \mathrm{O}\right]_{2} \cdot{ }^{[16]}$

The polyether length also plays a crucial role on the coordination sphere around the yttrium ion and, hence, on the thermal properties of the related adducts. In fact, there is evidence of an intriguing interplay between the polyether chain length and the yttrium ionic radius in determining the volatility of these adducts (see Figure 3 ). Therefore, small polyethers, such as the monoglyme or diglyme, form more volatile precursors. The longer triglyme and tetraglyme parent adducts have more complex coordination spheres and form the less volatile adducts $\mathbf{3}$ and $\mathbf{4}$, which are not so thermally stable. The coordinated $\mathrm{H}_{2} \mathrm{O}$ molecules in $\mathbf{3}$ are responsible for the two-step decomposition-evaporation, while the proposed ionic structure of $\mathbf{4}$ accounts for the higher melting point and consequent low volatility.

In this context, it becomes interesting to compare the measured melting points with those reported by Pollard et al. ${ }^{[19]}$ The observed data indicate that only the melting point of adduct $\mathbf{4}$ is quite similar. The data of $\mathbf{3}$ cannot be compared, since its melting point was not reported in ref. ${ }^{[19]}$ However, our melting point of $\mathbf{1}$ is about $20^{\circ} \mathrm{C}$ higher while that of $\mathbf{2}$ is about $20^{\circ} \mathrm{C}$ lower. It is important to note that adduct $\mathbf{2}$ has a slightly different X-ray single crystal structure but no explanation for the discrepancy observed in the case of $\mathbf{1}$ can be proposed. In any case, it is noteworthy that the melting point data were obtained by DSC measurement-curves and agree quite well with the Koeffler data.

Structural analogies between the yttrium adducts and those of the previously reported lanthanide homologues deserve further comments. This series of complexes is analogous to that observed for $\mathrm{Eu}^{[6]}$ and $\mathrm{Gd}^{[2]}$ but is different from that observed for La ions. ${ }^{[1,4]}$ In fact, in the case of La, completely different coordination spheres were found for adducts $\mathbf{1}, \mathbf{3}$ and $\mathbf{4}$. This indicates that in these compounds yttrium behaves like a smaller ionic radio lanthanon.

Close analogies with the diglyme La homologous precursor were found for $\left[\mathrm{Y}(\mathrm{hfa})_{3} \cdot\right.$ monoglyme] in terms of its ability to act as a solvent for other precursors, thus forming a multimetal liquid single MOCVD source. In particular, it dissolves the $\left[\mathrm{Ba}(\mathrm{hfa})_{2}\right.$.tetraglyme $]$ and $\mathrm{Cu}(\mathrm{tmhd})_{2}$ precursors and the formed melt represents a suitable source for the growth of YBCO thin films. The resulting in-situ growth of YBCO films using a single molten multimetal source is an important result. The multimetal mixture can be easily and cleanly evaporated from the melt with constant masstransport rates. On the contrary the sublimation of solid precursors suffers several drawbacks associated with sintering and surface passivation upon sublimation, which, in turn, render transport processes largely irreproducible.

Even more important, the use of precursors in a single liquid phase implies simpler reactor design and control of deposition parameters, since the interplay of control of different sublimation-evaporation parameters and carrier gas flows are no longer required.

In summary, the present procedure yields quantitatively nonhygroscopic adducts through a viable low-cost route. This represents an important issue for materials used in CVD applications, where low-cost chemicals that can be manipulated on open benches are an important objective. ${ }^{[24]}$ Furthermore the obtained raw materials are pure and the final products (no impurities are introduced in the one-pot synthesis) do not require further sublimation steps.

\section{Conclusions}

The present one-pot synthetic strategy has proven an efficient route for the preparation of thermally stable and volatile yttrium second-generation adducts from commercially available products. Thermogravimetric and vaporizationrate experiments indicate that they can be used in MOCVD deposition at temperatures lower than $200{ }^{\circ} \mathrm{C}$, with better mass-transport properties and thermal behaviour than conventional rare-earth metal CVD precursors. Furthermore because of their low melting points they can be used as thermally stable precursors in the liquid phase, hence under constant vaporization and mass-transport rates.

The effect of the polyether framework was widely investigated and the results emphasise the key role of the polyether length on the coordination sphere, which, in turn, affects the thermal stability and volatility of the adducts.

Finally, adduct $\mathbf{1}$ was tested as a solvent for a variety of precursors for YBCO deposition complexes, thus providing liquid single-sources, which simultaneously deliver all the metal components in the required stoichiometry. In the present work, the monoglyme yttrium adduct was used as a solvent for $\left[\mathrm{Ba}(\mathrm{hfa})_{2} \cdot\right.$ tetraglyme] and $\mathrm{Cu}(\mathrm{tmhd})_{2}$. The resulting multimetal, molten single-source was employed for the growth of highly textured YBCO films having good surface morphologies.

The present approach, which adopts a monocomponent, simple and low-cost MOCVD reactor, is an attractive alternative to the classical multicomponent MOCVD processes. 


\section{Experimental Section}

Reagents: Hhfa, monoglyme, diglyme, triglyme and tetraglyme (Aldrich) were used without any further purification. Yttrium nitrate $\left[\mathrm{Y}\left(\mathrm{NO}_{3}\right)_{3} \cdot 5 \mathrm{H}_{2} \mathrm{O}\right]$ was purchased from Aldrich.

General Procedures: Elemental microanalyses were performed in the Analytical Laboratories of the University of Catania. ${ }^{1} \mathrm{H}$ NMR spectra were recorded on a Varian Inova 500 spectrometer. Infrared data were collected on a 684 Perkin-Elmer spectrometer as nujol mulls between $\mathrm{NaCl}$ plates. Thermal measurements were made using a Mettler 3000 system equipped with a TG 50 thermobalance, a TC 10 processor and DSC 30 calorimeter. The weights of the samples were between 10-15 mg (TGA) and 4-8 mg (DSC). Analyses were carried out under prepurified nitrogen using a $5{ }^{\circ} \mathrm{Cl}$ min heating rate. $\mathrm{FAB}^{+}$mass spectra were obtained with a Kratos MS 50 spectrometer.

Synthesis of $\mathrm{Y}(\mathrm{OH})_{3} \cdot n \mathbf{H}_{2} \mathrm{O}: \mathrm{Y}(\mathrm{OH})_{3} \cdot n \mathrm{H}_{2} \mathrm{O}$ was precipitated from an aqueous solution of yttrium nitrate on addition of sodium hydroxide. The gelatinous precipitate was filtered and dried under vacuum over $\mathrm{P}_{4} \mathrm{O}_{10}$.

Synthesis of $\left[\mathrm{Y}(\mathbf{h f a})_{3} \cdot \operatorname{monoglyme}\right]$ (1): $\mathrm{Y}(\mathrm{OH})_{3} \cdot n \mathrm{H}_{2} \mathrm{O} \quad(1.482 \mathrm{~g}$, $10.59 \mathrm{mmol})$ was first suspended in hexane $(150 \mathrm{~mL})$. Monoglyme $(0.849 \mathrm{~g}, 9.42 \mathrm{mmol})$ was added to the suspension. Hhfa $(5.881 \mathrm{~g}$, $28.27 \mathrm{mmol}$ ) was added under vigorous stirring after $10 \mathrm{~min}$ and the mixture was refluxed whilst stirring for 1 hour. The excess of yttrium hydroxide was filtered off from the hot solution. White crystals precipitated after partial evaporation of the solvent. The colourless crystals were collected by filtration and dried under vacuum. The yield is $81 \%$. The melting point of the crude product is $74-77^{\circ} \mathrm{C} . \mathrm{C}_{19} \mathrm{H}_{13} \mathrm{~F}_{18} \mathrm{O}_{8} \mathrm{Y}$ (800.2): calcd. C 28.54, $\mathrm{H} 1.62$; found C $28.24, \mathrm{H} 1.56 \%$. The adduct sublimes quantitatively at $75-80$ ${ }^{\circ} \mathrm{C} / 10^{-3}$ Torr. IR (nujol or hexachlorobutadiene): $\tilde{v}=2930$ (vs), 1660 (s), 1610 (w), 1570 (m), 1540 (m), 1505 (m), 1455 (s), 1380 (m), 1250 (s), 1200 (s), 1150 (s), 1100 (m), 1040 (s), 1020 (m), 950 (w), $870(\mathrm{~m}), 830$ (vw), $800(\mathrm{~m}), 770(\mathrm{w}), 740$ (m), 660 (s), 600 (s), $530(\mathrm{~m}) \mathrm{cm}^{-1}$. The NMR, MS and IR data of the raw and sublimed adduct are identical.

Synthesis of $\left[\mathbf{Y}(\mathbf{h f a})_{3} \cdot\right.$ diglyme] (2): Prepared as described for the monoglyme adduct from $\mathrm{Y}(\mathrm{OH})_{3} \cdot n \mathrm{H}_{2} \mathrm{O}(1.152 \mathrm{~g}, 8.23 \mathrm{mmol})$, Hhfa $(4.411 \mathrm{~g}, 21.21 \mathrm{mmol})$ and diglyme $(0.948 \mathrm{~g}, 7.07 \mathrm{mmol})$. Yield 78 $\%$. The melting point of the crude product was $60-63{ }^{\circ} \mathrm{C}$. $\mathrm{C}_{21} \mathrm{H}_{17} \mathrm{~F}_{18} \mathrm{O}_{9} \mathrm{Y}$ (844.2): calcd. C 29.88, H 2.03; found C 29.25, H $2.25 \%$. The adduct sublimes quantitatively at $80-85^{\circ} \mathrm{C} / 10^{-3}$ Torr. IR (nujol or hexachlorobutadiene): $\tilde{v}=2930$ (s), 1660 (vs), 1605 (w), 1560 (w), 1530 (m), 1505 (s), 1460 (s), 1380 (m), 1260 (s), 1205 (s), 1140 (s), 1090 (s), 1055 (m), 1045 (s), 1010 (m), 950 (w), 870 (m), $835(\mathrm{w}), 800(\mathrm{~m}), 770(\mathrm{w}), 740(\mathrm{~m}), 660(\mathrm{~s}), 600(\mathrm{~s}), 535(\mathrm{w})$ $\mathrm{cm}^{-1}$. The NMR, MS and IR data of the raw and sublimed adduct are identical.

Synthesis of [ $\mathbf{Y}(\mathbf{h f a})_{3} \cdot\left(\mathrm{H}_{2} \mathrm{O}\right)_{2} \cdot$ triglyme] (3): Prepared as described for the monoglyme adduct from $\mathrm{Y}(\mathrm{OH})_{3} \cdot n \mathrm{H}_{2} \mathrm{O}(1.613 \mathrm{~g}, 11.52 \mathrm{mmol})$, Hhfa $(6.615 \mathrm{~g}, 31.80 \mathrm{mmol})$ and triglyme $(1.890 \mathrm{~g}, 10.60 \mathrm{mmol})$. Yield $88 \%$. Melting point of the crude product $52-55{ }^{\circ} \mathrm{C}$. $\mathrm{C}_{23} \mathrm{H}_{25} \mathrm{~F}_{18} \mathrm{O}_{12} \mathrm{Y}$ (924.3): calcd. C 29.86, H 2.70; found: C 29.25, H $2.57 \%$. The adduct sublimes quantitatively at $95-105{ }^{\circ} \mathrm{C} / 10^{-3}$ Torr. IR (nujol or hexachlorobutadiene): $\tilde{v}=3370(\mathrm{~m}), 3260(\mathrm{~m})$, 2930 (s), 1660 (s), 1560 (m), 1530 (m), 1505 (m), 1460 (s), 1370 (m), 1350 (w), 1255 (s), 1210(s), 1140 (s), 1100 (s), 1020 (w), 1005 (w), $940(\mathrm{w}), 840(\mathrm{w}), 800(\mathrm{~m}), 740(\mathrm{w}), 720(\mathrm{vw}), 660(\mathrm{~m}), 600(\mathrm{~m}), 535$ (w) $\mathrm{cm}^{-1}$. The NMR, MS and IR data of the raw and sublimed adduct are identical.

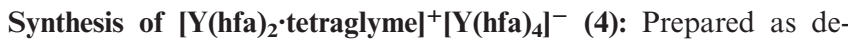
scribed for the monoglyme adduct from $\mathrm{Y}(\mathrm{OH})_{3} \cdot n \mathrm{H}_{2} \mathrm{O}(1.153 \mathrm{~g}$, $8.24 \mathrm{mmol})$, Hhfa $(4.410 \mathrm{~g}, 21.20 \mathrm{mmol})$ and tetraglyme $(1.570 \mathrm{~g}$, $7.067 \mathrm{mmol}$ ). Dichloromethane was used instead of hexane. Yield $65 \%$. The melting point of the crude product is $175-178{ }^{\circ} \mathrm{C}$. $\mathrm{C}_{40} \mathrm{H}_{28} \mathrm{~F}_{36} \mathrm{O}_{17} \mathrm{Y}$ (1553.5): calcd. C 30.9, H 1.81; C 28.83, H $1.89 \%$. The adduct sublimes quantitatively at $130-140{ }^{\circ} \mathrm{C} / 10^{-3}$ Torr. IR

Table 5. Crystal data and structure refinement for $\left[\mathrm{Y}(\mathrm{hfa})_{3} \cdot \operatorname{monoglyme}\right]$ and $\left[\mathrm{Y}(\mathrm{hfa})_{3} \cdot \operatorname{diglyme}\right]$

\begin{tabular}{|c|c|c|}
\hline Identification code & $\mathrm{Y}(\mathrm{hfa})_{3}$ Monoglyme & $\mathrm{Y}(\mathrm{hfa})_{3}$ Diglyme \\
\hline Empirical formula & $\mathrm{C}_{19} \mathrm{H}_{13} \mathrm{~F}_{18} \mathrm{O}_{8} \mathrm{Y}$ & $\mathrm{C}_{21} \mathrm{H}_{17} \mathrm{~F}_{18} \mathrm{O}_{9} \mathrm{Y}$ \\
\hline Molecular mass & 800.20 & 844.26 \\
\hline Temperature & $120(2) \mathrm{K}$ & $120(2) \mathrm{K}$ \\
\hline Wavelength & $1.54052 \AA$ & $1.54184 \AA$ \\
\hline Crystal system & Orthorombic & Orthorombic \\
\hline Space group & Pcab & $P c 2{ }_{1} n$ \\
\hline \multirow[t]{3}{*}{ Unit cell dimensions } & $a=16.095(5) \AA ; \alpha=90.00(5)^{\circ}$ & $a=11.151(5) \AA ; \alpha=90.00(5)^{\circ}$ \\
\hline & $b=17.983(5) \AA ; \beta=90.00(5)^{\circ}$ & $b=12.371(5) \AA ; \beta=90.00(5)^{\circ}$ \\
\hline & $c=20.753(5) \AA ; \gamma=90.00(5)^{\circ}$ & $c=22.251(5) \AA ; \gamma=90.00(5)^{\circ}$ \\
\hline Volume & $6007(3) \AA^{3}$ & $3070(2) \AA^{3}$ \\
\hline$Z$ & 8 & 4 \\
\hline Density (calculated) & $1.770 \mathrm{Mg} / \mathrm{m}^{3}$ & $1.827 \mathrm{Mg} / \mathrm{m}^{3}$ \\
\hline Absorption coefficient & $4.184 \mathrm{~mm}^{-1}$ & $4.157 \mathrm{~mm}^{-1}$ \\
\hline$F(000)$ & 3136 & 1664 \\
\hline Crystal size & $0.385 \times 0.502 \times 0.235 \mathrm{~mm}$ & $0.432 \times 0.416 \times 0.181 \mathrm{~mm}$ \\
\hline Theta range for data collection & 4.91 to $54.07^{\circ}$ & 4.44 to $58.03^{\circ}$ \\
\hline Index ranges & $0 \leq h \leq 16,0 \leq k \leq 18,0 \leq l \leq 21$ & $-1 \leq h \leq 12,-1 \leq k \leq 19,-22 \leq l \leq 22$ \\
\hline Reflections collected & 2906 & 8389 \\
\hline Independent reflections & $2788[R($ int $)=0.0988]$ & $3724[R(\mathrm{int})=0.0594]$ \\
\hline Refinement method & Full-matrix least-squares on $F^{2}$ & Full-matrix least-squares on $F^{2}$ \\
\hline Data/restraints/parameters & $2788 / 18 / 312$ & $3723 / 19 / 294$ \\
\hline Goodness-of-fit on $F^{2}$ & 1.005 & 1.058 \\
\hline Final $R$ indices $[I>2 \sigma(I)]$ & $R 1=0.1152, w R 2=0.2896$ & $R 1=0.0731, w R 2=0.1919$ \\
\hline$R$ indices (all data) & $R 1=0.1700, w R 2=0.3258$ & $R 1=0.0775, w R 2=0.1992$ \\
\hline Largest diff. peak and hole & 1.307 and $-1.626 \mathrm{eA}^{-3}$ & 2.192 and $-1.737 \mathrm{eA}^{-3}$ \\
\hline
\end{tabular}


(nujol or hexachlorobutadiene): $\tilde{v}=2930$ (s), 1650 (vs), 1605 (w), 1565 (m), 1540 (m), 1515 (m), 1495 (w), 1460 (s), 1380 (m), 1350 (w), 1260 (s), 1220 (s), 1200 (s), 1140 (s), 1100 (m), 1060 (m), 1035 (m), $950(\mathrm{~m}), 930(\mathrm{w}), 850(\mathrm{~m}), 830(\mathrm{vw}), 800(\mathrm{~m}), 770(\mathrm{w}), 740$ (m), $720(\mathrm{vw}), 660(\mathrm{~s}), 600(\mathrm{~s}), 535(\mathrm{~m}) \mathrm{cm}^{-1}$. The NMR, MS and IR data of the raw and sublimed adduct are identical.

X-ray Structure Determination: ${ }^{[25]}$ Single crystal X-ray diffraction patterns of mono-, di-, and triglyme adducts were obtained at room temperature using an ENRAF NONIUS CAD 4 four-circle diffractometer equipped with Mo- $K_{\alpha}$ radiation $(\lambda=0.71069 \AA)$. The triglyme derivative was found to be isomorphous with the outersphere complex already reported by K. D. Pollard et al., ${ }^{[19]}$ and, therefore, it was not analysed further. Diffraction data for the diglyme derivative were collected at $120 \mathrm{~K}$ using the same diffractometer and the unit-cell parameters were derived from leastsquares refinements of setting angles of 25 reflections in the $9-15^{\circ}$ range. Data are reported in Table 5 with other experimental parameters. No crystals were found to be isomorphous to the previously reported crystal structure. The new data for the monoglyme derivative single crystal were collected at $100 \mathrm{~K}$ using a diffractometer equipped with a CCD SMART $1 \mathrm{~K}$ area detector (Bruker) and a $\mathrm{Cu}$ rotating anode. Six series of $\omega$ scans were collected using the SMART software, ${ }^{[26]}$ each one of $0.3^{\circ}$ width and $10 \mathrm{~s}$ exposure time. The data were reduced using the software package SAINT. ${ }^{[27]}$ Completeness of unique data to $54.2 \theta$ were $97.4 \%$ with 0.97 redundancy and $98.3 \%$ with 3.31 redundancy for the mono- and diglyme derivatives, respectively. Cell parameters were determined from a nonlinear least square fit of the peaks collected in the first 620 frames.

Corrections were applied for Lorentz and polarization effects. The intensities of the diglyme adduct were corrected for absorption ( $\psi$ scan) while for the monoglyme derivative attempts to account for absorption were performed by using the DIFABS package without improvement in the refinements. The reflections were processed by the direct method program SIR $97^{[28]}$ which provided satisfactory sets of atomic parameters for yttrium and oxygen atoms. The other atomic parameters were determined by conventional Fourier difference synthesis by using the SHELX93 package ${ }^{[29]}$ up to the final results. The conventional agreement factor for the monoglyme adduct remained not satisfactory and therefore several crystals from different batches were examined. The data reported in Table 5 represent parameters with the lowest $R$ values. A residual thermal disorder prevented a better refinement of the data. Anisotropic displacement parameters were introduced for several non hydrogen atoms trying to maintain a good parameters/observable factor. The hydrogen atoms were included as idealized atoms riding on the respective carbon atoms with $\mathrm{C}-\mathrm{H}$ bond lengths appropriate to the carbon atom hybridization. The isotropic displacement parameters for each $\mathrm{H}$ atom were fixed 1.5 times the equivalent values of the bound carbon.

MOCVD Experiments: Low pressure MOCVD deposition of pure $(00 l)$-oriented YBCO films was carried out from the metal precursors $\left[\mathrm{Y}(\mathrm{hfa})_{3} \cdot\right.$ monoglyme $], \quad\left[\mathrm{Ba}(\mathrm{hfa})_{2} \cdot\right.$ tetraglyme $]$, and $\mathrm{Cu}(\mathrm{tmhd})_{2}$ using a horizontal hot-wall reactor. In each experiment a suitable mixture (see below) of yttrium, barium and copper precursors was used. The volatile liquid mixture was contained in a resistively heated alumina boat at $120{ }^{\circ} \mathrm{C}$ and was transported to the deposition zone by a $300 \mathrm{sccm}$ argon flow. YBCO thin films were deposited on $\mathrm{LaAlO}_{3}(100)$ substrates heated at $800{ }^{\circ} \mathrm{C}$. Water saturated $\mathrm{O}_{2}$ flow $(200 \mathrm{sccm})$ was used as the reaction gas and introduced near to the substrate. The water bubbler was maintained at room temperature. The mass flows were controlled with 1160
MKS flowmeters using an MKS 147 electronic control unit. The total pressure was maintained at 5 Torr during the growth process. The depositions were carried out for 180 minutes. YBCO thin films were slowly cooled to $500{ }^{\circ} \mathrm{C}$ at a low total pressure of 10 Torr $\left(\mathrm{P}_{\mathrm{O} 2}=4\right.$ Torr $)$. The annealing step at $500{ }^{\circ} \mathrm{C}$ was performed at atmospheric pressure in oxygen ambient for 12 hours.

$\mathrm{X}$-ray diffraction $\theta-2 \theta$ scans of thin films were recorded with a Bruker-AXS D $5005 \theta-\theta$ X-ray diffractometer using $\mathrm{Cu}-K_{\alpha}$ radiation operating at $40 \mathrm{kV} / 30 \mathrm{~mA}$. The pole figures were recorded on a Bruker-AXS D-5005 Texture X-ray diffractometer using $\mathrm{Cu}-K_{\alpha}$ radiation operating at $40 \mathrm{kV} / 30 \mathrm{~mA}$.

The atomic composition of the films was analyzed by energy dispersive X-ray analysis (EDX) using an IXRF detector. The surface morphology was examined with a Leo Iridium 1450 scanning electron microscope (SEM).

\section{Acknowledgments}

The authors thank the MIUR for financial support under Progetto Cluster 14 P.E. 2.

[1] G. Malandrino, R. Licata, F. Castelli, I. L. Fragalà, C. Benelli, Inorg. Chem. 1995, 34, 6233-6234.

[2] G. Malandrino, O. Incontro, F. Castelli, I. L. Fragalà, C. Benelli, Chem. Mater. 1996, 8, 1292-1297.

[3] G. Malandrino, I. L. Fragalà, S. Aime, W. Dastrù, R. Gobetto, C. Benelli, J. Chem. Soc., Dalton Trans. 1998, 1509-1512.

[4] G. Malandrino, C. Benelli, F. Castelli, I. L. Fragalà, Chem. Mater. 1998, 10, 3434-3444.

[5] G. Malandrino, R. Lo Nigro, F. Castelli, I. L. Fragalà, C. Benelli, Chem. Vap. Deposition 2000, 6, 233-238.

[6] G. Malandrino, M. Bettinelli, A. Speghini, I. L. Fragalà, Eur. J. Inorg. Chem. 2001, 1039-1044.

[7] K. D. Pollard, H. A. Jenkins, R. J. Puddephatt, Chem. Mater. 2000, 12, 701-710

${ }^{[8]}$ S. R. Drake, M. B. Hursthouse, K. M. Abdul Malik, S. A. S. Miller, D. J. Otway, Inorg. Chem. 1993, 32, 4464-4471.

[9] I. Baxter, J. A. Darr, M. B. Hursthouse, K. M. Abdul Malik, J. McAleese, D. M. P. Mingos, Polyhedron 1998, 17, 1329-1341.

${ }^{[10]}$ S. R. Drake, A. Lyons, D. J. Otway, A. M. Z. Slawin, D. J. Williams, J. Chem. Soc., Dalton Trans. 1993, 2379-2386.

${ }^{[11]}$ I. Baxter, S. R. Drake, M. B. Hursthuose, K. M. Abdul Malik, J. McAleese, D. J. Otway, J. C. Plakatouras, Inorg. Chem. 1995, $34,1384-1394$

${ }^{[12]}$ S. J. Kang, Y. S. Jung, Y. S. Sohn, Bull. Korean Chem. Soc. 1997, 18, 75-80.

${ }^{[13]}$ J. H. Lee, Y. S. Jung, Y. S. Sohn, S. J. Kang, Bull. Korean Chem. Soc. 1998, 19, 231-235.

${ }^{[14]}$ J. K. Marsh, J. Chem. Soc. 1947, 1084-1086.

${ }^{[15]}$ M. L. Hitchman, K. F. Jensen, Chemical Vapor Deposition: Principles and Applications Academic Press, London, 1993.

${ }^{[16]}$ H. A. Luten, W. S. Rees Jr., V. L. Goedken, Chem. Vap. Deposition 1996, 2, 149-161.

${ }^{[17]}$ A. Gleizes, S. Sans-Leinan, D. Medus, N. Hovnanian, P. Miele, J. D. Foulon, Inorg. Chim. Acta 1993, 209, 47-53.

${ }^{[18]}$ G. Malandrino, F. Castelli, I. L. Fragalà, Inorg. Chim. Acta 1994, 224, 203-207.

${ }^{[19]}$ K. D. Pollard, J. J. Vittal, G. P. A. Yap, R. J. Puddephatt, J. Chem. Soc. Dalton Trans. 1998, 1265-1268.

${ }^{[20]}$ S. J. Kang, Y. S. Jung, I. H. Suh, Bull. Korean Chem. Soc. 1999, 20, 95-98

${ }^{[21]}$ K. Timmer, C. I. M. A. Spee, A. Mackor, H. A. Meinema, A. L. Spek, P. van Der Sluis, Inorg. Chim. Acta 1991, 190, $109-117$.

[22] Experiments were performed with a temperature ramp up of $5{ }^{\circ} \mathrm{C} / \mathrm{min}$ under $\mathrm{N}_{2}$ and with a $4 \mathrm{~mm}$ alumina sample pan. 
[23] G. Malandrino, I. L. Fragalà, P. Scardi, Chem. Mater. 1998, 10, 3765-3768.

${ }^{[24]}$ J. T. Spencer, Progress in Inorganic Chemistry (Ed.: K. D. Karlin), Wiley: New York, 1994, 41, 145.

[25] CCDC-207289 (1) and -207290 (2) contain the supplementary crystallographic data for this paper. These data can be obtained free of charge at www.ccdc.cam.ac.uk/conts/retrieving.html [or from the Cambridge Crystallographic Data Centre, 12 Union Road, Cambridge CB2 1EZ, UK; Fax: (internat.) +44-1223336-033; E-mail: deposit@ccdc.cam.ac.uk].

[26] SMART: Area-Detector Integration Software.; Siemens Industrial Automation, Inc.: Madison, WI, 1995.
[27] SAINT, Version 4.0, Siemens Industrial Automation, Inc.: Madison, WI, 1995.

${ }^{[28]}$ A. Altomare, M. C. Burla, M. Camalli, G. L. Cascarano, C. Giacovazzo, A. Guagliardi, A. G. G. Molteni, G. Polidori, R. Spagna, SIR97: A New Program for Solving and Refining Crystal Structures, IRMEC-CNR, Bari, Italy, 1997.

[29] G. M. Sheldrick, SHELX 97, University of Göttingen, Germany, 1997.

Received June 9, 2003

Early View Article

Published Online November 28, 2003 